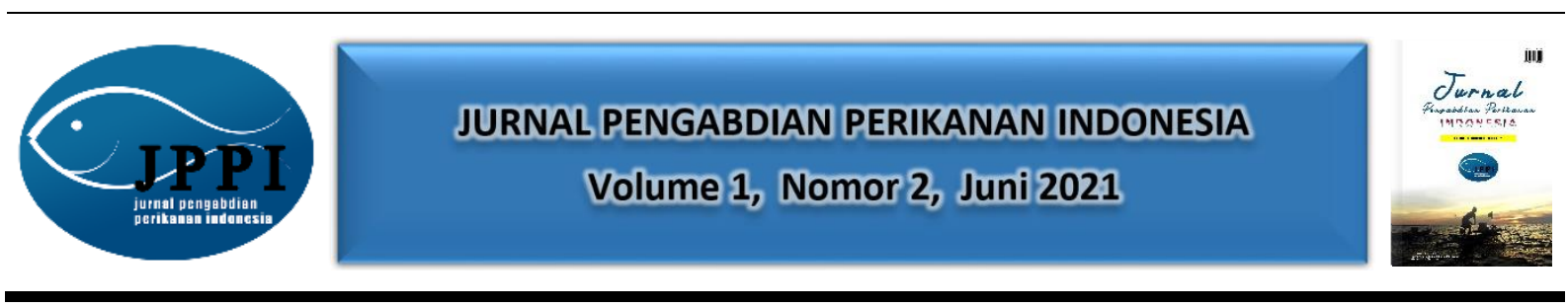

\title{
BUDIDAYA IKAN LELE DAN IKAN NILA OLEH KELOMPOK TANI TUNFEU DESA PONAIN KECAMATAN AMARASI KABUPATEN KUPANG DI MASA COVID-19
}

\author{
Mikson M. D. Nalle, Yusuf Kamlasi', Sri Imelda Edo \\ Program Studi Teknologi Budidaya Perikanan, Politeknik Pertanian Negeri Kupang \\ Jalan Prof. Herman Yohanes-Lasiana PO Box 1152 Kupang 85111 \\ *Alamat korespondensi : yusuf.kamlasi@gmail.com
}

(Tanggal Submission: 5 Juni 2021, Tanggal Accepted : 29 Juni 2021)

\begin{abstract}
Keyword : Abstrak :
budidaya, Desa Ponain telah ditetapkan sebagai desa siaga oleh pemerintah kabupaten Kupang ikan lele, dengan tujuan agar penduduknya memiliki kemampuan untuk mencegah dan covid-19, mengatasi masalah-masalah kesehatan, bencana dan keadaan gawat darurat dalam Tunfeu, bidang kesehatan secara mandiri dalam rangka mewujudkan desa sehat. Dengan Ponain pengetahuan yang terbatas Kelompok Tani Tunfeu ini sudah berhasil mengembangkan usaha tanaman pangan dan hortikultura serta peternakan. Tujuan kegiatan pengabdian untuk membantu meningkatkan pemahaman dan pengetahuan masyarakat tentang teknik pembesaran ikan; pemberian pakan, pencegahan penyakit dan kontrol kualitas air. Konstruksi wadah pemeliharaan ikan; pemilihan model yang tepat dan dan cara setting up wadah pemeliharaan. Metode pelaksanaan kegiatan meliputi survey, penyuluhan (penyampain materi, demplot) dan monitoring/pendampingan. Hasil yang diperoleh bahwa semua anggota kelompok sangat antusias mengikuti kegiatan mulai dari penyuluhan hingga demonstrasi dengan menerapkan protocol Covid-19. Kegiatan PKM dapat berjalan dengan baik dengan hasil yang sangat memuaskan hal ini mendapat apresiasi dari mitra bahkan masyarakat sekitar walaupun dalam suasana pandemic Covid-19. Mitra telah memperoleh pengetahuan tentang bagaimana teknik budidaya ikan khususnya budidaya ikan lele dan ikan nila dengan menggunakan kolam terpal serta bagaimana memasarkan hasil usahanya.
\end{abstract}

Panduan Sitasi (APPA $7^{\text {th }}$ edition) :

Nalle, M.M.D., Kamlasi, Y., \& Edo, S.I. (2021). Budidaya Ikan Lele Dan Ikan Nila Oleh Kelompok Tani Tunfeu Desa Ponain Kecamatan Amarasi Kabupaten Kupang Di Masa Covid-19. Jurnal Pengabdian Perikanan Indonesia, 1 (2), 151-156. http://doi.org/ 10.29303/jppi.v1i2.108

\section{PENDAHULUAN}

Kelompok Tani Tunfeu ini bergerak dalam bidang pertanian, peternakan dan perikanan dengan tujuan utama untuk membantu pemenuhan kebutuhan ekonomi keluarga. Desa Ponain diketahui 
telah ditetapkan sebagai desa siaga oleh pemerintah Kabupaten Kupang dengan tujuan agar penduduknya memiliki kemampuan untuk mencegah dan mengatasi masalah-masalah kesehatan, bencana dan keadaan gawat darurat dalam bidang kesehatan secara mandiri dalam rangka mewujudkan desa sehat. Dengan pengetahuan yang terbatas Kelompok Tani Tunfeu ini sudah berhasil mengembangkan usaha tanaman pangan dan hortikultura serta peternakan. Kelompok Tani Tunfeu sudah telah berdiri sejak tahun 2006 dan memiliki anggota aktif yaitu 26 KK. Kelompok tani ini memiliki keinginan yang sangat kuat untuk meningkatkan kualitas pelayanan mereka bagi masyarakat di Desa Ponain dan juga berkeinginan untuk memberikan contoh bagi kelompok atau bahkan desa tetangga yang lain untuk bergerak dalam memenuhi kebutuhan gizi pangan mereka melalui kegiatan produksi perikanan khususnya perikanan budidaya ikan air tawar. Dengan adanya diversifikasi produk perikanan budidaya berupa ikan air tawar, penghasilan kelompok dan anggota dapat meningkat.

Kegiatan budidaya ikan air tawar dewasa ini, semakin berkembang di Kota dan Kabupaten Kupang. Perkembangan budidaya tersebut erat kaitannya dengan meningkatnya pengetahuan masyarakat terhadap pemenuhan kebutuhan gizi keluarga dan perubahan pola konsumsi dari mengkonsumsi daging ternak seperti sapi, kambing, ayam dan babi menuju gerakan mengkonsumsi ikan. Ikan, baik ikan air tawar dan/atau ikan air laut memiliki kandungan protein yang relatif lebih tinggi dibandingkan daging dalam satuan berat tertentu. Disamping itu, ikan pada saat musimnya sangat melimpah sehingga harganya relatif lebih murah apabila dibandingkan dengan daging.

Ikan lele merupakan salah satu komoditas perikanan yang saat ini sedang marak diusahakan oleh masyarakat baik dalam skala besar maupun sekala kecil rumah tangga. Ikan lele merupakan komoditas yang sangat disukai masyarakat demikian juga dengan produk olahannya sangat digemari, hal ini dibuktikan dengan semakin berkembangnya usaha-usaha pengelolaan makanan atau kuliner oleh masyarakat yang berasal dari produk ikan lele baik dalam dalam skala besar dan kecil maupun pengolahan dalam bentuk yang lain (Kesuma, B. W, $d k k, 2019$ )

Ikan nila (Oreochromis niloticus) merupakan salah satu komoditas unggulan Indonesia yang memiliki potensi untuk dikembangkan dalam mendukung ketahanan pangan nasional maupun ketahanan ekonomi serta peningkatan kesejahteraan masyarakat. Ikan nila sebagai salah satu jenis ikan yang bernilai ekonomis tinggi, dimana kebutuhan benih maupun ikan konsumsi dari tahun ke tahun cenderung terus meningkat seiring dengan perluasan usaha budidaya (Darwisito et al., 2008 dalam Marie, et al., 2018)

Ikan air tawar yang mulai marak dibudidayakan di Kabupaten dan Kota Kupang adalah ikan lele, ikan mas, ikan nila dan ikan gurami. Pelaku budidaya sendiri tidaklah didominasi oleh kalangan petani saja melainkan juga masyarakat dengan beragam profesi dan penghasilan. Tahapan budidaya yang umumnya dikembangkan masyarakat adalah tahapan pembesaran dengan mengandalkan bibit yang berasal dari Pulau Jawa. Tahapan pembenihan sendiri masih kurang dilirik. Dari hasil diskusi dengan komponen petani dan masyarakat, tingkat pengetahuan dan pengalaman sering menjadi kendala utama. Tujuan kegiatan pengabdian untuk membantu meningkatkan pemahaman dan pengetahuan masyarakat tentang teknik pembesaran ikan, pemberian pakan, pencegahan penyakit dan kontrol kualitas air. 
Kelompok binaan yang dijadikan mitra kegiatan Program Kemitraan bagi Masyarakat (PKM) Program Studi Teknologi Budidaya Perikanan adalah Kelompok Tani Tunfeu berjumlah 26 KK yang terdiri dari petani yang sehari-harinya berusaha di bidang tanaman pangan, hortikultura dan peternakan yang ada di desa Ponain. Lokasi keberadaan kelompok ini terletak di Desa Ponain Dusun 4, RT 14, RW 07, Kecamatan Amarasi, Kabupaten Kupang. Karakteristik lokasi tempat tinggal kelompok merupakan daerah pertanian dengan sumber daya alam yang sangat potensial untuk dikembangkan baik untuk sektor pertanian maupun perikanan.

Metode pelaksanaan kegiatan pengabdian masyarakat di masa Pandemi Covid-19 ini secara tidak langsung berinteraksi dengan masyarakat desa. Adapun metode kegiatan pada program yang dilaksanakan adalah :

1. Survey

a. Melakukan koordinasi awal antara Tim dengan kelompok tani untuk mengenali kondisi mendapatkan data Profil kelompok

b. Pengajuan program kegiatan yang disampaikan pada saat koordinasi dengan aparat Desa beserta kelompok, dan pada tahap ini terdapat penyesuaian kegiatan terhadap kebutuhan dari kondisi

c. Permasalahan kelompok yang dikumpulkan dengan pendekatan partisipatif melalui hasil wawancara secara langsung sehingga sasaran dapat berperan aktif dalam setiap kegiatan dan penyelesaian masalah.

d. Berdasarkana identifikasi permasalahan, maka dibuat solusi untuk mengatasi permasalahan berupa pengetahuan (penyuluhan), monitoring dan pendampingan, diantaranya untuk peningkatan keterampilan dalam usaha budidaya ikan kepada Kelompok Wanita Tani Tunfeu.

2. Penyuluhan (penyampaian materi dan demplot)

Penyuluhan merupakan salah satu teknik dalam penyampaian pengetahuan kepada peserta tentang teknik budidaya ikan air tawar. Materi yang disampaikan berupa :

a. Teknik pembenihan ikan air tawar : cara memilih induk, pemeliharaan induk, pemberian pakan untuk induk, teknik kawin suntik, dan pemeliharaan larva.

b. Teknik pembesaran ikan; pemberian pakan, pencegahan penyakit dan kontrol kualitas air.

c. Konstruksi wadah pemeliharaan ikan; pemilihan model yang tepat dan dan cara setting up wadah pemeliharaan.

d. Cara Pembuatan Pakan Berbasis Bahan Lokal Sebagai pakan ikan air tawar

e. Analisis usaha pembesaran ikan lele dengan kolam terpal.

\section{Monitoring/Pendampingan}

Selanjutnya Monitoring/pendampingan akan dilakukan secara periodik dimulai sesaat setelah pemberian materi pokok, pelaksanaan demplot hingga berakhirnya keseluruhan rangkaian kegiatan. Berdasarkan pengalaman yang diperoleh pada saat dilakukan penyuluhan dan demplot untuk bekerja secara bersama-sama. Hal ini sekaligus melatih mereka untuk dapat bekerjasama dengan anggota lainnya dan agar peserta betul-betul dapat mengadobsi teknologi yang diberikan. Kegiatan ini akan didampingi atau dipantau langsung oleh tim pelaksana dengan harapan peserta betul-betul bisa mandiri. Hasil demplot diusahakan agar dapat diaplikasikan ke ikan yang dibudidayakan dan juga dijual di pasar untuk mengatahui nilai ekonomisnya.

Selanjutnya untuk menjamin lancarnya kegiatan dan membangkitkan rasa memiliki dari peserta kegiatan maka perlu kontribusi dan pratisipasi nyata peserta program. Kontribusi dan partisipasi mitra 
dalam kegiatan ini antara lain, lahan demplot, pembelian alat dan bahan lainnya untuk penyediaan sarana dan prasarana penunjang kegiatan pembuatan pakan ikan, mengalokasikan tenaga dan waktu.

\section{HASIL KEGIATAN}

Pelaksanaan kegiatan yang telah dilakukan pada lokasi PKM Program studi Teknologi Budidaya Perikanan di Kelompok Tani Tunfeu Desa Ponain telah selesai dan sesuai dengan tahapan kegiatan yang direncanakan yaitu:

1. Survey

Pada awal kegiatan dilakukan koordinasi awal, dosen dan kelompok tani mendiskusikan rencana kegiatan serta mengidentifikasi potensi serta permasalahan yang ada di kelompok, untuk menetapkan kegiatan PKM Budidaya ikan di masa Pandemi Covid-19 ini. Pengumpulan data/informasi dilakukan melalui wawancara dengan kelompok tani dan telaah terhadap profil kelomok. Selanjutnya Tim beserta menyusun program kerja dan menyiapkan berbagai bahan untuk kegiatan yang akan disosialisasikan pada pertemuan dengan masyarakat khususnya pada Kelompok Wanita Tani.

2. Pelaksanaan kegiatan penyuluhan

Kegiatan penyuluhan dilakukan dengan menggunakan metode ceramah dan demonstrasi. Metode ceramah yang dilakukan untuk menyampaikan berbagai informasi umum yang berkaitan dengan teknik-teknik budidaya ikan khususnya ikan lele dan ikan Nila. Sedangkan demontrasi untuk melakukan demplot sebagai pengalaman praktek terhadap peserta yang berkaitan dengan teknik-teknik budidaya ikan.

Lima Kompetensi yang berkaitan dengan teknik budidaya ikan telah diberikan kepada peserta antara lain: Dasar-dasar budidaya ikan, teknik konstruksi kolam terpal, teknik pembuatan pakan, manajemen kualitas air dan penanganan penyakit.

Hasil yang diperoleh bahwa semua anggota kelompok sangat antusias mengikuti kegiatan mulai dari penyuluhan hingga demonstrasi dengan menerapkan protocol Covid-19, bahkan terjadi diskusi yang hangat antara peserta dengan pemateri dan antara peserta dengan peserta walaupun dalam situasi pandemic covid-19. Suasana yang terjadi saat penyampaian materi berlangsung dengan baik bahkan peserta sangat antusias dalam mengikuti setiap tahapan yang direncanakan (Gambar 1).

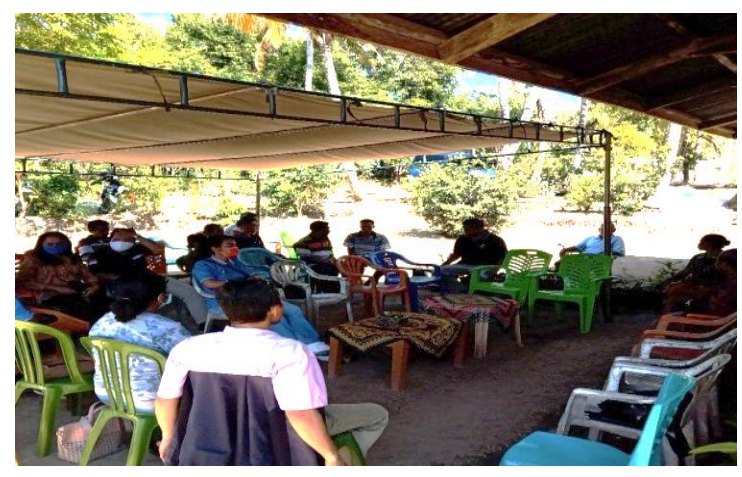

Gambar 1. Suasana Saat Penyampaian Materi

3. Pembuatan Kolam

Pembuatan kolam pada kegiatan PKM Program Studi Teknologi Budidaya Perikanan ini yaitu kolam terpal 3 unit dengan ukuran $2 \times 4 \mathrm{~m}$ berbentuk persegi panjang. Kolam dikonstruksi dari bahan dasar kayu yaitu kayu tongkat dan papan direkatkan dengan paku yang berfungsi sebagai penyokong. 
Sebelum pembuatan Kolam dilakukan penyerahan bahan untuk konstruksi berupa terpal, paku, dan kayu (Gambar 2).

Kolam yang dibuat ini memiliki masa pakai hingga 3 tahun dan cukup memadai sebagai awal untuk mitra dapat memiliki pengetahuan lapangan bagaimana teknik mengkonstruksi sebuah kolam yang baik. Tiga kolam yang dibuat memiliki kepadatan tebar bibit 1000 ekor/kolam.

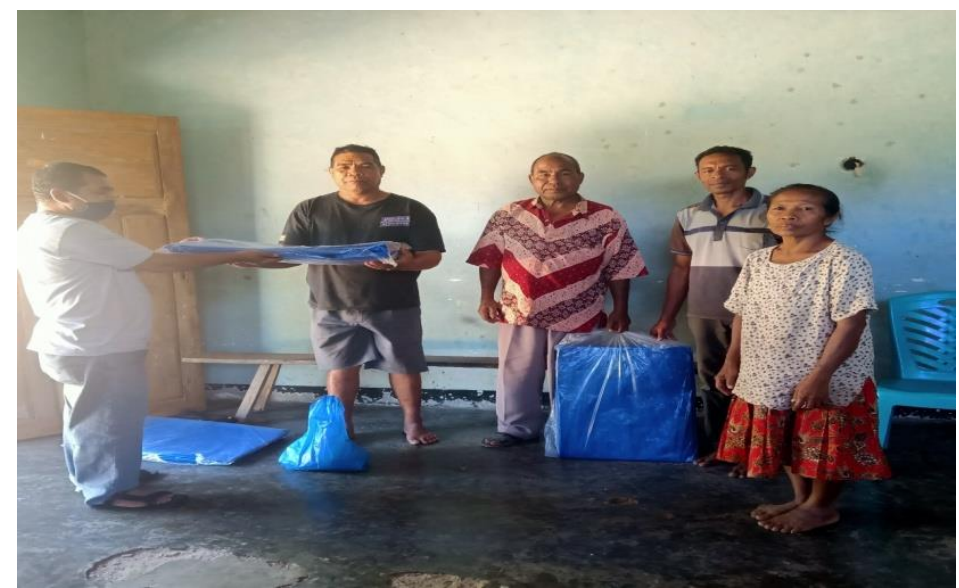

Gambar 2. Suasana saat penyerahan bahan untuk pembuatan kolam

\section{Penebaran benih}

Penebaran benih ikan pada kegiatan PKM program studi Teknologi Budidaya perikanan di Kelompok Tani Tunfeu Desa Ponain ini sebanyak 1500 ekor terdiri dari 1000 ekor benih lele dan 500 ekor benih Nila. Benih ikan nila yang akan ditebar di kolam pembesaran diaklimatisasi terlebih dahulu untuk menyesuaikan suhu di lingkungan baru. Peralatan dan bahan yang digunakan antara lain plastik, air, dan oksigen.

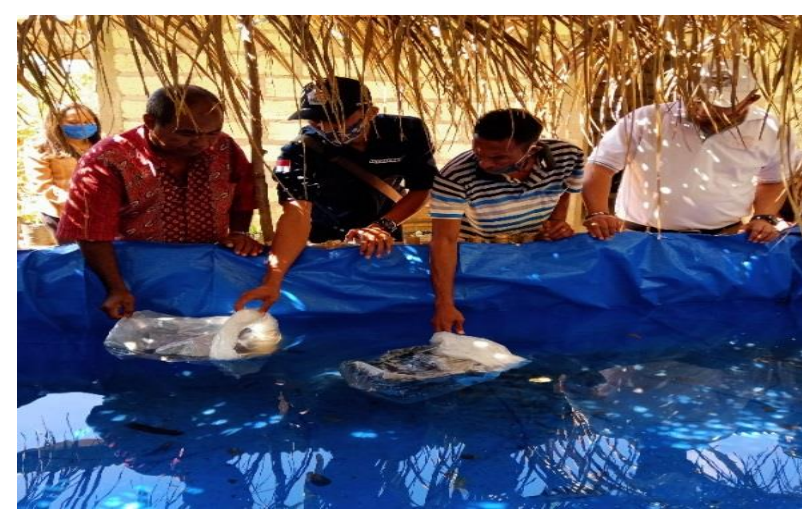

Gambar 3. Suasana saat penebaran benih.

\section{Pendampingan}

Pendampingan yang diberikan pada mitra yaitu dimulai dari awal pelaksaan kegiatan yaitu penyuluhan, pembuatan kolam, pembuatan pakan bahkan masih berlangsung hingga selesai. Kegiatan pendampingan ini dimaksudkan untuk memonitor setiap aktivitas yang dilakukan oleh mitra, agar supaya kegiatan budidaya ikan lele mulai dari penebaran hingga proses pembesaran dapat berlangsung dengan baik.

Hasil yang diperoleh bahwa hingga saat ini mitra terus melakukan aktifitas untuk pembesaran ikan dan hingga sekaran ikan sudah berumur 2,5 bulan dengan berat 8 ekor $/ \mathrm{kg}$. 


\section{KESIMPUAN DAN SARAN}

\section{Kesimpulan}

Berdasarkan Hasil Program Kemitraan Masyarakat Program Studi Teknologi Budidaya Perikanan Tahun 2020 yang telah dilakukan, maka dapat kesimpulan adalah:

1. Kegiatan PKM dapat berjalan dengan baik dengan hasil yang sangat memuaskan hal ini mendapat apresiasi dari mitra bahkan masyarakat sekitar walaupun dalam suasana pandemic Covid-19.

2. Mitra telah memperoleh pengetahuan tentang bagaimana teknik budidaya ikan khususnya budidaya ikan lele dan ikan nila dengan menggunakan kolam terpal serta bagaimana memasarkan hasil usahanya.

\section{Saran}

Kegiatan diharapkan dapat dilanjutkan oleh mitra sebagai contoh terutama kepada masyarakat sekitar lokasi PKM.

\section{DAFTAR PUSTAKA}

Kesuma, B. W, Budiyanto dan Bieng Brata (2019). Efektifitas Pemberian Probiotik Dalam Pakan Terhadap Kualitas Air Dan Laju Pertumbuhan Pada Pemeliharaan Lele Sangkuriang (Clarias gariepinus) Sistem Terpal Jurnal Penelitian Pengelolaan Sumberdaya Alam dan Lingkungan.

Marie, Mochammad Ali Syukron dan Seto Sugianto Prabowo Rahardjo (2018). Teknik Pembesaran Ikan Nila (Oreochromis niloticus) dengan Pemberian Pakan Limbah Roti Jurnal Sumberdaya Alam dan Lingkungan. 